\title{
Decolonizing the Boundaries: Indigenous Musical Discourse in the History of Kurdish Radio Baghdad
}

\author{
Jon E. Bullock \\ Dept. of Music, University of Chicago \\ bullockj@uchicago.edu
}

\begin{abstract}
Divided between empires and nation-states for centuries the Kurds have, by and large, been excluded from discourses of indigeneity. In a similar manner, musical practice among the Kurds cannot be easily cajoled into Western categories such as folk/popular. How then might scholars begin to approach the decolonization of research describing Kurdish musical practice? In this article, I propose that one important step in this process is learning to pay closer attention to the ways Kurdish musicians themselves have challenged the colonial legacy, adeptly navigating, challenging, and sometimes simply ignoring the political, linguistic, and cultural boundaries established by their colonizers. As an example of this practice, I describe key moments of resistance in the early history of Kurdish Radio Baghdad. I argue that accepting these acts of resistance as a form of indigenous musical discourse is an important first step toward the decolonization of Western knowledge in this regard.
\end{abstract}

KEYWORDS: Kurds; Iraq; Radio Baghdad; Indigeneity; Decolonization; Folk/Popular

\section{Introduction}

On 19 November 1939, while much of the world was still riveted by Germany's invasion of Poland just weeks prior, Iraq's Kurds celebrated a momentous occasion: the state radio station Radio Baghdad's very first segment in Kurdish. The station had started its regular Arabic broadcasts just three years earlier in July 1936, and to many, this first Kurdish segment must have seemed like quite the victory. Under the British occupation and Mandate (1918-1932), Iraq's Kurds had struggled against a colonial system in which Kurdish was not used in schools after the level of primary education. Furthermore, bureaucratic documents and announcements were only sporadically issued in Kurdish, and Kurdish language reformers were not permitted 
to Romanize the Sorani dialect's alphabet, as language reformers would soon do for the Kurmanji dialect widely spoken in the Kurdish regions of Turkey (Hassanpour 1992: 118-119). Before its Mandate for Iraq expired, Britain had helped to install a monarchy that it hoped would ensure the continuation of its own presence in the region, lending credence to poet and anti-colonial theorist Aimé Césaire's (1955: 43) observation that "in general the old tyrants get on very well with the new ones, and that there has been established between them, to the detriment of the people, a circuit of mutual services and complicity". Under this new monarchy, Iraq's Kurds fared even worse in the area of language recognition as the government's promises to the Mandate Commission were ignored and schools and administrative centers in the liwas of Mosul and Kirkuk were subjected to Arabization (Hassanpour 1992: 118). A radio broadcast in Kurdish, then, was big news indeed.

Like so much of Kurdish history in Iraq and other nations where Kurds have faced state suppression in one form or another, the details of the first Kurdish broadcast do not seem to have survived. In his book describing the history of the Kurdish section of Radio Baghdad, renowned Kurdish singer Bakurî (2009: 4) notes only that the first broadcast's listeners heard one or two records of Kurdish music and a news report focusing primarily on the quickly escalating second world war. Even without additional details, however, what we do know about the broadcast is telling. The first segment, which included Kurdish music, reveals the importance of the early recording industry in Iraq, which was already well established before the founding of Radio Baghdad, and whose own history reflects colonial interference in Iraq in ways I describe in further detail below. The second segment highlights the impact of World War II on the emerging Iraqi broadcasting industry, an impact that would result not only in continued colonial interference in local affairs, but also in the founding of entirely new stations and programs broadcasting in Kurdish from Jaffa and Beirut. Together, these two segments show that colonial power was central to the formation of Iraqi Kurdish broadcasting from the beginning, particularly as colonial powers attempted to shape the nascent Iraqi recording and broadcasting industries in ways favorable to their own interests. If, as Stephen Blum and Amir Hassanpour (1996: 330) suggest, "radio broadcasting has contributed, more than any other factor, to the formation of a [Kurdish] listening public with access to music on a daily basis", how might scholars begin to understand this history without reinforcing or even replicating the colonial power that made it possible in the first place?

In this article, I propose that one important step in this process is learning to pay closer attention to the ways Kurdish musicians themselves have challenged the colonial legacy, adeptly navigating, critiquing, and sometimes simply ignoring the political, linguistic, and cultural boundaries established by their colonizers. Before examining this process through key moments in the early history of Kurdish Radio Baghdad, I begin by highlighting the ways colonial power was central to the early recording industry in Iraq, whose national boundaries were drawn by colonial powers after the end of World War I. I then describe how the practice of drawing boundaries has also been replicated in various forms of academic discourse, including that on indigeneity and the imagined folk/popular divide in music, and has therefore continued to subject Kurds to a form of colonial power. By returning to the ways Iraqi Kurdish musicians have historically resisted other forms of colonial power, I provide a model through which I suggest we might begin to approach the decolonization of the realm of knowledge production regarding Kurdish (and other forms of) music-making. 


\section{Colonialism and the Early Recording Industry}

In their introduction to An International History of the Recording Industry, Ilpo Saunio and Pekka Gronow (1998: ix) assert that "the development of recordings has, ultimately, been guided by those who, invisible to the public eye, are responsible for the choice of repertoire and who reconcile the sometimes conflicting claims of art and commerce". Far more than just a competition between the dreamers and the money-makers, the early history of the recording industry reflects the importance of colonial power, alliances, and access. As one brief example, consider the relationship between the US-American Victor Talking Machine Company and its sister company headquartered in London, the Gramophone Company. In 1900, Gramophone became the first company to record in the Ottoman Empire, and around 1907, the company established an office in Alexandria, Egypt (Bresler). At the time, Britain's relations with the Ottomans had not yet soured, and Egypt was still considered a protectorate of Britain. As other major recording companies raced to establish offices all across the globe, the sister companies Victor and Gramophone reached an agreement whereby Victor would focus on the Western hemisphere, China and Japan, (all regions where US influence was growing), and Gramophone would take the East, where British colonies ensured no shortage of ready and available markets (Gronow 1982: 4). Simultaneously, as the Germans began increasing their presence in the Middle East as part of the country's "drive to the East" (Drang nach Osten), German company Odeon made the most of its exclusion from any such agreement, sending agents all over the world, and producing 11,000 Arabic, Greek, and Turkish records alone by 1906 (Vernon 1997) [1].

As tensions between colonial powers like Britain, France, and Germany rose around the turn of the twentieth century, nationalist movements started to ignite across the Middle East alongside the apparent decline of the Ottoman Empire. Local expressions of nationalist fervor were often tied to the production of records in local languages, and smaller record companies such as Macksoud, which specialized in Arabic recordings, began to loosen the grip of the commercial giants. Another of these local companies, Baidaphon, was founded in Beirut around 1907 by five members of the Lebanese Christian Baydā family (Racy 1976: 39-40). Interestingly, the company chose to found its first office and begin producing its records in Berlin, a decision ethnomusicologist A. J. Racy (1976: 41-42) argues could suggest the aid of representatives from Odeon. Over the next few decades, as Middle Eastern intellectuals across the region participated in debates related to pan-Arab and other forms of nationalism (and as many began cultivating close ties with the Germans), Baidaphon experienced immense success, establishing new offices in Cairo, Damascus, Baghdad, and Marrakesh. Even more significant, Baidaphon soon began using Arab nationalist tropes as a central feature of its marketing. After 1911, for example, the company began printing a gazelle on its record labels; the gazelle had long been invoked in Arabic literature as a symbol of grace and beauty, unlike the common dog that was featured on labels produced by His Master's Voice (Racy 1976: 42). In addition to its recordings of Middle Eastern star vocalists such as Egyptians 'Abd al-Wahhāb, 'Abd al-Hayy Hilmī, and Sayyid al-Saftī, Baidaphon also began producing a series of blatantly nationalist recordings. In 1928, for example, the company offered to bring the Jewish Tunisian actress and singer Habiba Messika to its main office in Berlin. Messika had first risen to fame in the 1920s after recording for Pathé and later Gramophone, but traveling to Berlin, far from the eyes of Tunisia's French colonizers, provided her the opportunity to record 
nationalist songs praising Egypt's King Fuad; Muhammed VI, Bey of Tunis; and even King Faysal of Iraq (Silver 2018).

As these examples make clear, the Middle East was swept into the international quest for a monopoly on the recording industry shortly after the turn of the twentieth century, as US-American, European, and Middle Eastern (and other regional) record companies began competing for access to commercial markets, recording technology, and the best regional singers. In many cases, the ensuing battles were fought along lines reflective of pre-existing or contemporary colonial conquests and alliances, particularly as colonial powers sought to expand their reach into the region. For Kurdish singers in particular, many of whom remained Ottoman subjects until the Empire's collapse following World War I, the race for commercial success provided new opportunities to record for those who could afford to travel to cities like Baghdad, and dozens of companies (both global and regional) produced records featuring Kurdish singers like 'Elî Es⿱艹̈er Kurdistanî (1882-1936), Miryem Xan (1904-1949), and Miḧemed 'Arif Cizîrî (1912-1986). Although Kurdish nationalism as a popular movement was not yet fully formed at this time (van Bruinessen 1992: 25-26), the impact of these records would only grow stronger with the birth of the broadcasting industry in the region. Aside from providing the early radio stations with Kurdish music for broadcasting, the process of producing these records contributed the commercial frameworks for the establishment of a growing network of Kurdish musicians who would ultimately become leaders in these industries. More importantly, Kurdish nationalist resistance would soon enter an entirely new phase alongside the collapse of the Ottoman Empire (which had also exerted modern forms of colonial power over its Kurdish populations for decades), moves by colonial Western powers to occupy the Middle East during and after World War I, and the ongoing colonization of Kurdish territories by new nation-states created after the signing of the Treaty of Lausanne in 1923. The cumulative result of these events was that after 1923, Kurds across the region found themselves suddenly divided by new national boundaries they had not helped to create.

\section{Kurdish Resistance and the Creation of Modern Iraq}

If the history of the early recording industry in Iraq reflects traces of colonial power and alliances, the drawing of Iraq's boundaries by Western powers after the end of World War I provides a dazzling glimpse of colonial power at full strength. Although Kurds had been divided among the Ottoman and various Persian empires since long before the twentieth century, the gradual weakening of the Ottoman Empire in particular provided several Kurdish leaders with hope that the time had finally come to establish an independent Kurdistan. One of the earliest nationalist revolts was led by Shaykh 'Ubayd-allāh in southeast Anatolia in 1880-1881; according to historian Wadie Jwaideh (2006: 76), this particular revolt, though unsuccessful, signaled the crystallization of a new stage of Kurdish nationalism. Heartened by US President Wilson's calls for self-determination during and after World War I, many Kurds dared to hope that the dissolving of the Ottoman Empire would finally allow the creation of a Kurdish state. This, of course, was not to be; whereas the Treaty of Sèvres (1920) had specifically mentioned the possibility of Kurdish national autonomy, the treaty that replaced it, the Treaty of Lausanne (1923), made no mention of the Kurds whatsoever. While the treaty's signing and the conclusion of the seemingly endless land disputes it helped to solve was celebrated as a success, the majority of Kurds found themselves once again divided, this time among the new nation-states of Turkey, Syria, Iraq, and Iran. Iraqi Kurdish 
poet Choman Hardi hints at the absurdity of this moment of defeat in her poem "Lausanne, 1923": "Sitting around an old table/ they drew lines across the map/ dividing the place/ I would call my country".

For the Kurdish populations of the new postwar states, far more was at stake than mere lines on a map. One by one, these new states passed laws aimed at fostering national culture, often to the exclusion of Kurdish and other minority languages and cultures. In the new Republic of Turkey, which some describe as having colonized its own ethnic Kurds throughout much of the twentieth century (Turkyilmaz 2016), the state instituted "linguistic genocide" against the Kurds as official policy in 1923. Turkish was promoted as the state's official language, and Kurds faced punishments of fines, violence, or even separation from family members for speaking or writing in Kurdish (Hassanpour 1992: 118). Even before the founding of the Republic of Turkey, Turkish officials had unsuccessfully attempted to retain control of the wilayet of Mosul in what is now northern Iraq (Ali 2017), leading to a clash of colonial powers that continues to resound in Turkey's recent military incursions into both Syrian (Iddon 2020) and Iraqi Kurdistan ("Turkish fighter jets attack PKK sites in northern Iraq", 2020).

In Iran, Persian was declared the nation's only official language in 1906, and under Reza Shah (1925-1941), Kurds faced arrest and sometimes even torture for speaking in their mother tongue (Hassanpour 1992: 126). As I have already suggested, Kurds in Iraq fared only slightly better under British occupation and, later, the British-installed monarchy; nevertheless, since it had the loosest restrictions on speaking and singing in Kurdish during this period, Iraq became an increasingly important site for recording Kurdish singers from all parts of Kurdistan. Crucial to this process was the earlier establishment of local recording companies such as Baidaphon and Chakmakchi, which was originally founded as a seller of electronics in Baghdad in 1918 and is remembered today for its recordings of famed Iraqi singers Nāzim Al-Ghazālī and Muhammed Al-Qabānjī (Ward 2010). Were it not for local companies such as these, Kurds may not have been able to record at all in the decades immediately following World War I as a result of both the general disruption of operations experienced by Western recording companies during and after the war, and the new proscriptions against the Kurdish language in some neighboring countries.

As Kurdish performers from Turkey and Iran reacted to the suppression of Kurdish culture by making their way to Baghdad to record, local leaders in Iraq's Kurdish regions plotted ways to resist British colonial interference, which would be given the official stamp of approval by the League of Nations' Permanent Mandates Commission in 1920. One of the most notable nationalist leaders during this time was Șêx Meḧmûd, who, with the support of tribal forces from nearby Persian Kurdistan, declared himself the leader of an independent Kurdistan in the city of Silêmanî in 1919 (Jwaideh 2006: 180). Not to be outdone, the British colonizers responded quickly and with force, squelching the shaykh's rebellion within a month, and sentencing him to exile in another British colony-India (Jwaideh 2006: 182). Later acknowledging their need for the shaykh's broad support base, however, the British brought Șêx Meḧmûd back to Kurdistan several years later, and in November 1922, he once again declared a revolt against the British. This time, the government responded by flexing their power over the skies, bombing the shaykh's headquarters multiple times and conducting a months-long series of air demonstrations over the city of Silêmanî (Jwaideh 2006: 195-202).

The political and cultural importance of the shaykh and his rebellion is reflected in the song "Șêx Meḧmûd", which was recorded several years after the events 
described above by Kawês Aẍa (1889-1936). A singer whose own struggles in the cultural realm seem to mirror the shaykh's in the realm of the political, Kawês Aẍa is affectionately remembered by many today as the "nightingale of Kurdistan" (bulbulî Kurdistan). While I have not been able to find data regarding the original reception of "Șêx Meḧmûd", the broader story of Kawês Ä̈a's rise to success is telling of broader attitudes toward both the recording industry and resistance to colonial power. Kawês Aẍa was born into the Herkî tribe, members of which today live in several different regions of Kurdistan and speak the Kurmanji dialect. Herkî leaders had played an active role in supporting the nationalist aims of Shaykh 'Ubayd-Allāh, as they later would those of Qadî Mï̈emed, who led the short-lived Mehabad Republic in Iran in 1946 (Oberling 2012). During the first world war, Kawês Aẍa was forced to flee the city of Ruwandiz (also Rewandiz, Riwandiz), as were many of the city's other inhabitants, when the Russians attacked the city as part of the Caucasus Campaign in 1916. After the war, Kawês Ä̈a chose not to return to the city, and in 1930, having learned a large repertoire of regional songs and having become quite famous in various parts of Kurdistan, he decided to travel to Baghdad in the hopes of winning a recording contract. Despite the strength and clarity of his singing voice, Kawês Ä̈a reportedly stuttered while speaking. According to several accounts, the recording executives in Baghdad laughed at his stammering pleas for a record deal, retorting something along the lines of "You can't even speak; how could you possibly sing?" Broken hearted, Kawês Ä̈a went across the street to a Kurdish-owned teahouse, where he sat down and started to sing a song called "Genc Xelîl". The melancholy sounds of Kawês Ä̈a's voice filled the air, wafting through the windows of the recording company's office, and before long, the record company executives who had turned him away came running across the street to see whose voice they were hearing. Upon realizing their mistake, they apologized profusely and offered a recording contract. Fittingly, the first song Kawês Ä̈a recorded was "Genc Xelîl" (Kawîs Ä̈a).

Far more than just a story hidden in some dusty archive, the narrative of Kawês Ä̈a's success is still a part of musical discourse in Iraqi Kurdistan; in fact, it often comes up in my own ethnographic interviews with musicians in the city of Silêmanî. As I see it, the story is one that speaks directly to the threat that colonial power unleashed against Kurdish language and culture more broadly, and to the power of small acts of resistance on the part of Kurdish musicians. At its most basic level, the story is a powerful testament to the strength of Kurdish musical practice; after all, it was singing and not speaking that revealed the recording executives' gross underestimation of the beauty and value of Kurdish culture. Furthermore, I find it significant that the very site from which Kawês Ä̈a challenged the recording executives' narrative was a teahouse, and one owned by Kurds. In the early days of recording, Kurdish teahouse owners were among the first to purchase phonographs and later radios, and teahouses became important sites for listening to music communally. The Kurdish owners of the teahouse in the story were no doubt less likely to silence the broken-hearted musician (traditional Kurdish songs often deal with the grief of death or separation), and the teahouse's proximity to the recording studio provides a powerful illustration of the relative proximity (and yet invisibility) of Kurdish culture in Iraq. At the same time, it was the recording industry and not anyone in the nearby government offices in Baghdad that provided the possibility of preserving Kurdish culture for posterity.

By the time of his death in 1936, Kawês Ä̈a had recorded dozens of songs that would later be broadcast over the radio from the Kurdish section of Radio Baghdad. 
Among the fifty-two of his songs recently released on CD by the Kurdish Heritage Institute in Silêmanî, six are from the genre known as beste, eight from the genre of heyran, and thirty-eight from the genre known as lawik. Lawiks often narrate epics or stories related to love or war, and they are still regarded as a difficult genre to perform. It seems likely that the genre originated in the Turkish regions of Kurdistan (often referred to as Bakûr), but within Iraq, the genre is now most often associated with the region of Badînan, where the local dialect is related to both Kurmanji (the most common dialect in Turkish Kurdistan) and Sorani (the predominant dialect in Iraqi Kurdistan). Kawês Ä̈a performed the lawik "Șêx Meḧmûd" in the Badînî dialect, and it seems likely that the recording and later the broadcasting industries including those in Baghdad and in other cities such as Yerevan, the site of a station that proved particularly influential for Kurds in Turkey (Yüksel 2011), were responsible for popularizing this and other songs that had previously been considered part of regional genres. Although many of these genres are still considered regional to this day, many Kurdish listeners at least recognize them, lending credence to the notion that the musical mapping of the Kurdish regions in this way can also be considered a form of resistance to colonial logics of place (i.e., the demarcation of Kurdistan by national boundaries rather than an understanding of Kurdistan as a mosaic of unique linguistic/cultural regions).

Of the many lawiks recorded by Kawês Ä̈a, notable are those praising not only Șêx Meḧmûd, but also other nationalist leaders such as Simko Ä̈a, who led a Kurdish revolt in Persia in 1922, and Șêx Ë̈med Barzanî, brother to the famed nationalist leader Meła Mistefa Barzanî. The lawik praising Șêx Meḧmûd recounts the story of his defeat by the British in June 1919 (during his first revolt against the British) at the Battle of Bazyan Pass. The battle followed a particularly embarrassing loss to the British as Șêx Meḧmûd's forces resisted their first attempt to reassert their authority over Silêmanî and the surrounding areas. As Britain's civil commissioner in Baghdad at the time, Sir Arnold Wilson, expressed regarding the British defeat (Jwaideh 2006: 181):

This 'regrettable incident' confirmed the now general belief of the inhabitants of Southern Kurdistan that we were no longer able to control events; the rebellion spread across into Persian territory, and several tribes rose against the Persian Government, proclaiming themselves partisans of Shaikh Mahmud and of his scheme for a free and united Kurdistan.

The British retribution, which included attacks from two infantry brigades, cavalry forces, armored cars, and an air force unit, resulted in the wounding and subsequent capture of Șêx Meḧmûd.

As the British response to these events illustrates, the greatest threat to British colonial rule was not the prospect of armed rebellion, but rather the perception among Kurdish leaders that the British were not strong enough to maintain control of the region-in other words, that colonial power was a farce. I have found no evidence to suggest that the British ever heard Kawês Ä̈a's recordings praising Șêx Meḧmûd, Simko Ä̈a, or other nationalist leaders, much less that they attempted to censor them in any way. This is not to suggest, however, that Kurdish musicians were free from the effects of colonial power, as I have argued in relation to the story of Kawês Ä̈a's success, but rather that colonial power was reinforced in multiple ways. Anthropologist Talal Asad (1992: 333) describes this process in his essay "Conscripts of Western Civilization" as follows: 
Today it is not merely 'primitive cultures' that are shattered by more powerful 'civilization'; all societies that anthropologists study are being destroyed and remade by the forces that were unleashed by European imperialism and industrial capitalism. The modern world is now structured as a power domain in which political, economic, and ideological processes interact directly, regardless of distance, and where historical agents in very different places are obliged to address aspects of identical problems. To say this is not to assert that the globe is socially homogenous, or that non-European societies have lost their cultural 'authenticity'. Such claims have been made or denied by travelers, anthropologists, and political ideologues for generations. My point is a different one: that social and cultural variety everywhere increasingly responds to, and is managed by, categories brought into play by modern forces.

Even in the recording studios of Baghdad, then, Kurdish musicians were forced to respond to the rapid changes that colonial power was effecting across the region. For some like Miryem Xan and Mïhemed 'Arif Cizîrî, the answer was to leave their homes in Turkey, where speaking Kurdish had been declared a criminal offense against the state, and to migrate to Baghdad, where they continued to record. Those Kurds who remained in Turkey witnessed the "Turkification" of many Kurdish traditional songs for broadcasting by the national public broadcaster of Turkey (TRT), the Turkish Radio and Television Corporation (Yüksel 2011). For others, like Kawês Ä̈a, resistance meant preserving the heroic feats of leaders like Șêx Meḧmûd in epic form, matching one technological threat (bombing from the air) with another (recording).

The various forms of resistance by Kurdish musicians during this period would prove foundational in later years as Iraq's Kurds were finally allowed access to the airwaves. As I have already mentioned, one of the effects of these events was the popularization of a wide variety of regional styles and even linguistic dialects. Another was the preservation of Kurdish musical culture, which would increasingly come under attack throughout the latter half of the twentieth century. Before moving on to discuss these later forms of resistance, however, I first turn toward a broader discussion of the ways colonial power continues to impact the modern categories of knowledge characteristic of academic scholarship. After all, as Talal Asad's argument above makes clear, the impact of colonialism did not end with the British evacuation of Iraq (nor did it suddenly begin again in 2003 with the US-led invasion); in other words, the colonization of Iraq was not a historical event with a start and end date, but rather the beginning of an ongoing process.

\section{Decolonizing the Boundaries of Academic Discourse}

In summer 2018, historian Nilay Özok-Gündoğan wrote an essay inspired by two recent Kurdish Studies conferences hosted by US universities. In the essay, titled "Kurdish Studies in North America: Decolonizing a Field that Does Not Quite Exist, Yet?", Özok-Gündoğan asserts, "Kurdish Studies is currently caught between seemingly contradictory but equally vital agendas: building the field as an independent field of inquiry in North America while simultaneously struggling to free it from the paradigm of area studies" (2018). Often associated with US imperial aspirations during the Cold War, the birth of area studies has rightly come under criticism in recent years as glorifying the ideal of the nation-state at the expense of other social, cultural, and political formations, and as inseparable from foreign policy decisions, even though scholars of the Middle East in particular have been decreasingly involved in (or consulted on) US foreign policy (Armbrust 2000, 2-6). 
For Özok-Gündoğan, the challenge ahead of Kurdish Studies, then, is two-fold: first, to legitimize Kurdish Studies as an area of study backed by institutional support, and second, to incorporate Kurdish Studies into broader expanses of interdisciplinary research that avoid the pitfalls of the area studies paradigm.

The task of decolonization has also been a primary focus of attention for many music scholars, as illustrated by the Fall/Winter 2016 edition of the Society for Ethnomusicology's (SEM) student newsletter, SEM Student News. The theme of the issue is "Decolonizing Ethnomusicology", and the issue's call for submissions "invited critical discussion of ethnomusicology as a field of practice, asking contributors to draw attention to the significance of diversity in perspectives and representation" while also inviting "reflexive critique of our positions, actions, responsibilities, and relationships within communities where we are engaged as graduate students and ethnomusicologists" (Rosenberg 2016: 1). Following the call for submissions, editors of the newsletter's "Student Voices" column released a voluntary online survey on the subject of decolonizing ethnomusicology as a discipline. In the survey's second section on participants' personal views on this process, the twenty-five participants provided answers that were subsequently grouped into four categories in the final publication: "1) decentering ethnomusicology from the United States and Europe; 2) expanding/transforming the discipline; 3) recognizing privilege and power; and 4) constructing spaces to actually talk about decolonizing ethnomusicology among peers and colleagues" (Alarcón-Jiménez 2016: 6). The problems raised by these goals are strikingly similar to the five chronic problems outlined a decade earlier by ethnomusicologist Steven Loza (2006: 362) in his article "Challenges to the Euroamericentric Ethnomusicological Canon: Alternatives for Graduate Readings, Theory, and Method". The problem areas outlined by Loza include 1) the general dependence of the university on "Euroamericentric" canons, theories, and methods; 2) hegemonic views of issues such as time, place, and metaphor; 3) the lack of minority representation among academic faculty and researchers; 4) the lack of diversity in university curricula; and 5) the problematic fetishizing of "Theory" in academic research.

Despite decades of widespread calls such as these aimed at decolonizing music scholarship, the process of decolonization is one with which many scholars continue to grapple. After all, the boundaries of the contemporary Middle East are not the only result of imperial Western forces flexing their colonial power; academic discourse emanating primarily from the West has also created boundaries of its own that make projects such as decolonizing the study of Kurdish music increasingly difficult. One potential reason for this seeming paradox is the association between modern power, which is never too far removed from academic discourse, and destruction. As Talal Asad (1992: 340) further explains in "Conscripts of Western Civilization":

My concern ... is to stress something that is not in dispute: that a new world has been forcibly created as a consequence of the West's imperial adventure, and that the categories (political, economic, cultural) in terms of which that world has increasingly come to live have been put in place by characteristic modalities of modern power. Destruction-whether it was carried out by Europeans or by non-European rulers anxious to defend themselves by attempts at Westernization-interests me here only to the extent that it is integral to modern power, especially the power of the modern state. 
One of the more immediate implications of this kind of destruction for Kurds is related to the continued elevation of the nation-state as the only appropriate model for dignity and self-determination. Such an insistence not only ignores centuries of preexisting social and political formations among the Kurds, but also redirects contemporary discourse on Kurdish nationalism toward the founding of a Kurdish state and away from other important problems such as political corruption and human rights abuses in areas where some degree of Kurdish autonomy has already been attained. It also stands to reason that in addition to the destruction wrought by the very idea of the modern nation-state, destruction is also a potential result of (usually) well-meaning academics who approach their research in terms of categories of knowledge and knowledge production that marginalize local ways of knowing and responding to colonial power. The resulting destruction of local discursive categories inflects how these scholars access, interpret, and represent the histories of those among whom they work.

One important example of this latter kind of destruction can be seen in discourse related to the notion of indigeneity. While the concept is often utilized as part of an attempt to acknowledge the colonial past and to move toward a decolonized future, it can just as often be used (wittingly or unwittingly) to reinforce the very nonindigenous categories through which indigenous voices are expected to respond. As media scholar Jo Smith and English professor Stephen Turner (2013: 271) assert in particular relation to New Zealand, "A more recent global love of all things Indigenous disguises continuing colonialism: New Zealand is probably a world leader here ... In this context, postcolonialism describes new as well as more established measures of controlling a Māori body that will ultimately not be governed in non-Māori terms". For Kurds, the problem is not that they have yet to be given access to indigeneity as a particular kind of status, or that settler logics disavow local ways of thinking, acting, and being (particularly since the British never attempted to settle Iraq), but rather that pervasive colonial logics of place and time proscribe the very notion of "Indigeneity" (particularly in the global-political sphere), thereby preventing the emergence of other, more localized expressions.

Two important examples in this regard-both from other peoples residing in the Middle East-involve the Bedouin population of the Negev in Israel and the Assyrian Christians of Iraq. For the most part, discourse on indigeneity has largely ignored the Middle East, highlighting instead those geographical areas subjected to centuries of European settler colonialism. In recent years, however, both of these groups have made claims to indigeneity before various legal or international assemblies. For Israel's Bedouins of the Negev, the claims to indigeneity reflect the desire of various members among the Bedouin leadership to circumvent the Ottoman-era legal framework that recognizes them only as Arabs or Palestinians, and therefore demarcates their land as state land (Frantzman et al 2011: 96). For Iraq's Assyrian Christians, the attempt to claim indigenous status is a direct response to the erasure of Assyrian culture and history, as well as the forced removal from ancestral homelands that was carried out by Islamic State militants in June 2014. Sargon George Donabed and Daniel Joseph Tower (2018) describe some of the problems associated with Assyrian claims to indigeneity as follows:

Indigenous peoples such as the Assyrians break the mold of the discussion, because the actions of European colonizers form only one part of the group's history. Briefly, Assyrians were colonized by the British and French, as were most other Middle Eastern peoples. They had also experienced colonization in a different context at the hands of Western Catholic and Protestant missionaries, who were unable to make much headway in predominantly 
Muslim communities. Even earlier, Assyrians had experienced multiple waves of Arab/Islamic colonial conquest. They now live amid a burgeoning Kurdish nationalist project. In other words, colonization is not a solely Europeanoriented matter.

Highlighting the common association of resistance to colonial projects with heroism, Donabed and Tower go on to assert that "Middle Eastern indigeneity, it seems, doesn't exist without a Western gaze".

Although discourse on indigeneity has not been particularly central to Kurdish nationalist movements, there is a growing sense that Kurds, too-particularly those in Turkey - should begin to claim indigenous status as a way of demanding equal citizenship, communal recognition by the state, the right to education in Kurdish, and the right to self-determination (Ünal 2017: 65). While this may seem like a worthwhile endeavor, the previous cases illustrate the particular difficulties of demanding that indigeneity be recognized as applicable to the entire Middle East so long as international bodies such as the United Nations refuse to acknowledge the political implications of self-determination for all indigenous peoples. Of course, the greater problem I am attempting to outline here is not that indigeneity is a weak principle politically, but rather that it often requires the acceptance of particular (colonial) logics of place and time. Whenever it elevates the supposed $a$ priori land rights of indigenous peoples above all other aspects of indigenous expression, for example, the very notion of indigeneity demands a linear historical encounter with colonial power (the colonizer) that precedes the forcible removal of a group of people (the colonized) from a specific piece of land. As Donabed and Tower make clear, this narrow definition of indigeneity excludes most of the Middle East.

In a seminal article detailing Kurdish-Armenian relations at the turn of the twentieth century, historian Janet Klein notes that the question of land ownership among minority groups is often far more complex than the average historical narrative reveals. In the case of southeast Anatolia during the late Ottoman Empire, Klein (2007: 155) argues that nomadic Kurds and settled Armenians often shared access to the same land over the course of a year, and that the development of violence among these two communities can be seen as a direct result of political and social changes that disenfranchised both Armenian and Kurdish peasants. The colonial logic of land as reflective of a particular type of claim to indigeneity therefore works to exclude groups such as Kurds, Armenians, and Assyrians from indigeneity as a category of representation and affirmation. Likewise, the insistence of the colonial logic that indigenous peoples lived in definable geographic clusters of space in a time period pre-dating the arrival of (primarily European) colonizers does not allow space for the particular histories of groups with complex and repeated historical interactions not only with multiple colonizers, but also with each other. To put it rather bluntly, the histories of Kurds, Armenians, and Assyrians did not begin when the British invaded Iraq in 1914.

In addition to the constraining nature of discourse on indigeneity, the decolonizing of research on Kurdish music must also account for the artificial boundaries that have been constructed between "folk" and "popular" forms of music-making. As music scholar Ross Cole (2019: 32-34) asserts in a recent edition of Ethnomusicology, the theory of "folk song" popularized by Cecil Sharp in early twentieth-century Britain (one that remains influential today) was ultimately responsible for the creation of a logic that equated the peasant with the primitive, the nation with "a racial community with sacred ties to the soil". At its most 
extreme, Cole asserts that this principle is not so different from fascist ideology, and that the "folk song was a less pernicious expression nonetheless predicated on the very same system of thought" (35). Like discourse on indigeneity, this understanding of "folk" music as a particular representation of a group of people or as reflective of an "essential reference to social structures" (Strohm 2018: 6) relies on colonial logics of place and time insofar as it demands a particular relation to both modernity and the nation (in the literal geographic sense). For Kurds in Turkey, the politicization of folk songs beginning in the 1990s offers one recent example of the breakdown of the boundaries between "folk" and "popular" forms of Kurdish music-making, particularly since politicized folk songs arranged in various Western styles have become a common feature among diasporic Kurdish youth musicians whose networks are often formed through cultural centers in metropolitan areas (Aksoy 2006).

In ethnographic interviews, the word that my Iraqi Kurdish interlocutors most often use to describe the kinds of songs researchers would typically describe as "folk songs" is not originally Kurdish; in fact, it is the word folklor. The use of this word seems to signify that the demarcation of particular kinds of music as "folk" music is not an original feature of Kurdish musical discourse. This theory seems to be born out in practice as well, as it is quite common to hear traditional and contemporary styles and compositions played back-to-back without distinction in public spaces. It is also not unusual for Kurdish musicians to perform contemporary renditions of songs recorded nearly a century ago to the accompaniment of drum sets, guitars, and keyboards; rarely (except in sponsored televised settings aimed at promoting official versions of "folkloric" Kurdish culture) do musicians ascribe to them a primary sort of historical or preservationist relevance. Instead, these songs have become so ingrained in local musical memory that they seem to exist not as historical artifacts to be assigned an original time and place (although of course, many are quite capable of offering these details if asked), but as living expressions that are molded to fit the unique circumstances of each performance. Furthermore, these songs are often blended seamlessly into sets that include songs in Arabic, Turkish, Persian, or Western languages such as Italian and English, reflecting the sense that Kurdish musicians ply their craft as part of a regional and global practice and not just a local one. How, then, if not through the common lens of folk/popular or other generic paradigms, might we view "folkloric" Kurdish songs as part of a broader history of Kurdish music-making, and particularly one that was forged alongside and reactive against the power of colonialism? As a way of answering this question, I now return to the point in Kurdish history at which I began-the founding of a Kurdish section of Radio Baghdad.

\section{Kurdish Radio Baghdad and the Makings of Iraqi Kurdish Music}

The arrival of recording and broadcasting technology in Iraq signaled the start of a new period in the young nation's history. For Iraq's Kurds, recording technology provided a critical way of ensuring cultural and linguistic survival in times of uncertainty. Throughout the 1920s and 1930s, as a number of aspiring Kurdish singers made the long journey to Baghdad in the hopes of recording their songs, they often did so at their own expense or for hardly any pay. The instrumentalists who normally accompanied these singers rarely joined the vocalists on their journey; instead, they rehearsed with the singers in their local towns (Chingiani 2019). These groups of instrumentalists would ultimately prove seminal in the later 
formation of local music groups in cities such as Silêmanî, Kirkuk, and Hewlêr (Erbil), the region's capital city. At the time, however, the singers who were able to record did so accompanied by groups in Baghdad who were employed by the recording companies and who were comprised largely of Arab and Jewish musicians [2]. The emerging importance of Baghdad as a center for music education and recording possibilities for Kurdish musicians cannot be overstated; as a former employee of Kurdish Radio Baghdad once told me, in those years, anyone with dreams of any kind went to Baghdad (Abbas 2019).

By the early 1930s, radio sets were beginning to appear in the larger cities of Iraqi Kurdistan. The first radio in the city of Silêmanî was purchased in 1932 by the owner of a local teahouse (Hassanpour 1996: 72). The set is reported to have attracted the attention of many of the local men, who began visiting the teahouse after the evening adhān each day to witness the "wonderful device... which speaks without a person" and to listen to the Qur'ān (Necim 2019). In 1936, the fledgling Iraqi government founded its own state radio station, powered by a single mediumwave transmitter (Boyd 1999: 124-125). Until 1941, stations were unable to broadcast live music, and as such, all the music played at the station was played from records [3]. After the founding of the Kurdish section of Radio Baghdad and the development of live broadcasting technology, the station eventually hired its first Kurdish musician: 'Elî Merdan (d. 1981), who is remembered even today as the "king of maqam". Merdan was born in the city of Kirkuk in 1904; his father was a tobacco seller and caravan leader, and as such, Merdan had the opportunity to travel the region extensively from a young age. The young Merdan was reportedly fascinated by several local Qur'ānic reciters and performers of maqam, and as he traveled the region carrying tobacco for his father, he began learning local Kurdish genres such as Qetar, Xawker, Hore, Xurşîd, and Ay Ay [4]. During journeys to Baghdad, Merdan also learned how to perform Persian dastgahs and Arab maqams, including Iraqi maqams. In 1932, he journeyed to Egypt to attend the Cairo Congress of Arab Music, traveling with Iraqi Jewish performers on the violin, oud, and qanun (Necim 2019).

If the decades before Merdan's appearance on Kurdish radio had seen the establishment of a growing network of Kurdish musicians centered in Baghdad, Merdan's life and career trajectory illustrate the ways that growing network straddled multiple linguistic, political, and cultural boundaries, incorporating Kurdish musical practices, musicians, and genres from distinct regions within Iraqi Kurdistan and from other parts of Kurdistan as well, all while circulating within the broader realm of a distinctively Middle Eastern musical practice. Under Merdan's watch, this growing network of musicians soon included other now-famous Kurdish singers such as Tayêr Tofîq (d. 1987), Resûl Gerdî (d. 1994), Bakurî, Nesrîn Şêrwan (d. 1990), and Ḧesen Zîrek (d. 1972), a singer from Iranian Kurdistan who is said to have recorded as many as 1,000 songs during his lifetime. In his role at Radio Baghdad, Merdan served as a manager of sorts for these and other vocalists in addition to training the station's ensemble of mostly Arab, Jewish, and Christian musicians how to perform the Kurdish songs (Necim 2019). It was thus during this time that Iraqi Kurdish music first began to develop as a distinct form of musical practice, and its early inclusivity and situatedness within a broader regional musical practice seems to have laid the foundation for contemporary attitudes toward music such as those described in the previous section.

By the end of World War II, the daily time allotment for the Kurdish section of Radio Baghdad had increased to one hour; this allotment would continue to increase over the next several decades, despite the various state policies that would 
result in political suppression and even genocide among Iraq's Kurds (Hassanpour 1992: 283). Potential reasons for this seeming contradiction are several: first, the historical record reveals that there were actually moments of real progress, in which Iraqi government managers of the station truly seemed interested in supporting the cause of Kurdish radio. Second, even had the government wanted to stamp out the propagation of Kurdish cultural materials, Iraqi broadcasting had already proven inferior in the battle for the air waves as seen in the case of Egypt's broadcasts condemning the Baghdad Pact [5]. Had Kurdish Radio Baghdad been shut down, Kurds no doubt would have shifted their attention to Kurdish broadcasts coming from Tehran, Yerevan (not far from the site of the very first Kurdish radio broadcasts), or other locations such as Beirut and Jaffa, where the French and the British respectively supported Kurdish-language broadcasts as a result of fears that Nazi propaganda was influencing public opinion against them in Iraq (Bakurî 2009, 6). In fact, many of the Kurdish vocalists who performed or recorded in Baghdad also did so at stations in other parts of Kurdistan anyway. Alongside the existence of these other stations, the seeming porousness of national boundaries for many Kurdish musicians served to insulate the industry as a whole from destructive attempts levied by colonial and later state power.

\section{Conclusion}

As recent historical protests across the globe have shown, the work of decolonizing systems of power and privilege is the greatest task of our time. Eve Tuck and K. Wayne Yang assert in their 2012 article of the same name, "Decolonization is not a metaphor", and they insist that its work should be incredibly unsettling. As I have argued here, however, the work of decolonizing scholarship on musical practice requires more than good intentions and a willingness to sacrifice personal comfort or even property; decolonization also requires attending to the very frames through which we encounter and claim to represent the musical practices and histories of colonized peoples-in other words, the boundaries we ourselves as academics impose or sustain. As I have argued throughout this article, even concepts (like indigeneity) that are meant to provide a way forward must be reexamined in light of their own internal colonial logics [6]. In addition to rejecting these logics, I have argued here that one important step in the process of decolonizing music scholarship is learning to pay closer attention to the ways colonized peoples themselves have challenged the colonial legacy and responded to colonial power, as well as state power built on colonial models. For Iraqi Kurds, this means acknowledging the ways Iraqi Kurdish music history does not support the typical understanding of Kurdish nationalist movements as inherently oppositional or of Kurds as helpless victims of colonial power, but instead tells a story of the formation of a transnational network of musicians that included men, women, Christians, Jews, Muslims, Kurds, and Arabs alike. By taking part in a state-operated broadcasting system in a state often hostile to their very existence, Iraqi Kurdish musicians created new forms of mass-mediated Kurdish culture that crossed multiple boundaries and continue to influence Iraqi Kurdish musicians to this day. Acknowledging this history, which I have only begun to outline here, as a form of indigenous musical discourse (rather than continuing to exclude Kurds from discourse on indigeneity) is an important first step toward the decolonization of Western music scholarship in this regard. To do otherwise-to continue to insist on the use of well-worn frames of representation-is to assume that only scholars themselves can do the work of decolonization, and to continue building on the 
hegemonic power structure that gives us a scholarly platform at the expense of those we claim we want to help free from the legacies of colonial power. This, of course, is precisely the point - the work was never ours alone to accomplish.

\section{Endnotes}

1. By contrast, Columbia produced only 6,000 "foreign" records in its E-series between 1908 and 1923 (Gronow 1982: 3).

2. A number of famous Kurdish singers at this time, particularly women, were also Jewish. These included Daykî Cemal and Nesrîn and Esmer Ferhad, two sisters "discovered" by the Kurdish radio station's first broadcaster, Kamîl Kakemîn.

3. Stations began broadcasting live music around 1941, but they did not possess the technological capability to record their own broadcasts until the early 1950 s.

4. Even today, it is rare for a Kurdish singer to be as well-versed in multiple regional genres.

5. For decades, Iraq's broadcasting capabilities seemed miniscule compared with those of some other nearby nations. In the mid-1950s, the country begged the United States for help attaining higher power transmitters to combat Egyptian broadcasts criticizing Prime Minister Nuri Al-Said and his support for the pro-Western Baghdad Pact. Even after the military coup of General Abdul Karim Qasim in 1958 (and perhaps especially so), Iraqi leaders maintained their political interest in radio, expanding the number of broadcasting hours and purchasing higher quality equipment whenever possible.

6. Even Tuck and Yang (2012) seem to fall back on the insistence of land's importance in relation to de-colonization; as I have stressed elsewhere, this narrow understanding of place actually can reinforce colonial notions of land occupation and ownership.

\section{References}

\section{Bibliography}

Aksoy, Ozan. 2006. The Politicization of Kurdish Folk Songs in Turkey in the 1990s. Music and Anthropology 11.

Alarcón-Jiménez, Ana-Marнa. 2012. Student Voices: A Student Union Column.

SEM Student News 12 (2): 5-10. https://cdn.ymaws.com/www. ethnomusicology.org/resource/group/dc75b7e7-47d7-4d59-a66019c3e0f7c83e/publications/SEMSN12.2.pdf. .Accessed 15 June 2020.

Ali, Othman. 2017. The career of Ozdemir: a Turkish bid for northern Iraq, 1921 1923. Middle Eastern Studies 53 (6): 966-985.

Armbrust, Walter. 2000. Introduction: Anxieties of Scale. In W. Armbrust Ed. Mass Mediations: New Approaches to Popular Culture in the Middle East and

Beyond. Berkeley: University of California Press: 1-31.

Asad, Talal. 1992. Conscripts of Western Civilization. In C. Gailey Ed. Dialectical Anthropology: Essays in Honor of Stanley Diamond, vol. 1. Gainesville, FL: University Press of Florida: 333-351.

Bakurî, Endriyos. 2009. Ézge ("Station"). Hewlêr, Iraq: Çapxaney Şehab.

Blum, Stephen and Hassanpour, Amir. 1996. 'The Morning of Freedom Rose up': Kurdish Popular Song and the Exigencies of Cultural Survival. Popular Music 15 (3): 325-343. www.jstor.org/stable/931333. . Accessed 15 June 2020. 
Boyd, Douglas A. 1999. Broadcasting in the Arab World: A Survey of the Electronic Media in the Middle East, $3^{\text {rd }}$ ed. Ames, IO: Iowa State University Press.

Bresler, Joel. 78 RPM Sephardic Recordings. https://www.sephardicmusic.org/ 78survey.htm. Accessed 15 June 2020.

Césaire, Aimé. 1955. Discourse on Colonialism. Translated from French by Joan Pinkham, 2000. New York: Monthly Review Press.

Cole, Ross. 2019. On the Politics of Folk Song Theory in Edwardian England. Ethnomusicology 63 (1): 19-42.

Donabed, Sargon George and Tower, Daniel Joseph. 2018. Reframing Indigeneity: The Case of Assyrians in Northern Mesopotamia. https:// www.historians.org/publications-and-directories/perspectives-on-history/ january-2018/reframing-indigeneity-the-case-of-assyrians-in-northernmesopotamia. Accessed 15 June 2020.

Frantzman, Seth J. et al. 2011. Contested Indigeneity: The Development of an Indigenous Discourse on the Bedouin of the Negev, Israel. Israel Studies 17: 78-104. http://dx.doi.org/10.13140/2.1.3904.5763.

Gronow, Pekka. 1982. Ethnic Recordings: An Introduction. In American Folklife Center Ed. Ethnic Recordings in America: A Neglected Heritage: 1-50. Washington: Library of Congress.

Gronow, Pekka and Ilpo Saunio. 1999. Introduction. In Pekka Gronow and Ilpo Saunio An International History of the Recording Industry: viii-ix. Translated from Finnish by Christopher Moseley. New York: Cassell.

Hassanpour, Amir. 1992. Nationalism and Language in Kurdistan, 1918-1985. San Francisco: Mellen Research University Press.

Iddon, Paul. 2020. The tragic consequences of Turkey's colonization of Syria's Kurdish Afrin region. Global Comment. http://globalcomment.com/the-tragicconsequences-of-turkeys-colonization-of-syrias-kurdish-afrin-region/. Accessed 25 November 2020.

Jwaideh, Wadie. 2006. The Kurdish National Movement: Its Origins and Development. Syracuse: Syracuse University Press.

Klein, Janet. 2007. Conflict and Collaboration: Rethinking Kurdish-Armenian Relations in the Hamidian Period (1876-1909). International Journal of Turkish Studies 13 (1 and 2): 153-166.

Loza, Steven. 2006. Challenges to the Euroamericentric Ethnomusicological Canon: Alternatives for Graduate Readings, Theory, and Method.

Ethnomusicology 50 (2): 360-371. www.jstor.org/stable/20174460. Accessed 15 June 2020.

Necim, Umêd. (2019) Facebook group Radyoy Kurdî Komarî 'Êraqe le Beẍda ("Kurdish Radio of the Republic of Iraq in Baghdad"), 4 September. Available from: https://bit.ly/3dgKs70 Accessed 15 June 2020.

Oberling, P. 2012. "Harki". In Encyclopaedia Iranica. http://www.iranicaonline. org/articles/harki. Accessed 15 June 2020.

Özok-Gündoğan, Nilay. 2018. Kurdish Studies in North America: Decolonizing a Field That Does Not Quite Exist, Yet?. https://www.jadaliyya.com/Details/ 37676. Accessed 15 June 2020.

Racy, Ali Jihad. 1976. Record Industry and Traditional Egyptian Music: 19041932. Ethnomusicology 20 (1): 23-48. www.jstor.org/stable/850819. Accessed 15 June 2020. 
Rosenberg, Davin. 2016. Letter from the Editor. SEM Student News 12 (2): 1-2. https://cdn.ymaws.com/www.ethnomusicology.org/resource/group/dc75b7e747d7-4d59-a660-19c3e0f7c83e/publications/SEMSN12.2.pdf. Accessed 15 June 2020.

Silver, Chris. 2018. The Life and Death of North Africa's First Superstar. https://www.historytoday.com/miscellanies/life-and-death-north-africas-firstsuperstar. Accessed 15 June 2020.

Smith, Jo and Turner, Stephen. 2013. Indigenous Inhabitations and the Colonial Present. In Graham Huggin Ed. The Oxford Handbook of Postcolonial Studies: 271-288. Oxford: Oxford University Press.

Strohm, Reinhard. 2018. Tradition, Heritage, History: A View on Language. Musicological Brainfood: Tasty Bite-Size Provocations to Refuel Your Thinking 2 (1): 6-10.

Tuck, Eve and Yang, K. Wayne. 2012. Decolonization Is Not a Metaphor. Decolonization: Indigeneity, Education, and Society 1 (1): 1-40. https:// clas.osu.edu/sites/clas.osu.edu/files/Tuck\%20and\%20Yang\%202012\%20Decol onization\%20is\%20not\%20a\%20metaphor.pdf. Accessed 15 June 2020.

'Turkish fighter jets attack PKK sites in northern Iraq'. 2020. Aljazeera. https:// www.aljazeera.com/news/2020/6/15/turkish-fighter-jets-attack-pkk-sites-innorthern-iraq. Accessed 25 November 2020.

Turkyilmaz, Zeynep. 2016. Maternal Colonialism and Turkish Women's Burden in Dersim: Educating the "Mountain Flowers" of Dersim. Journal of Women's History 28 (3): 162-186.

Ünal, Aynur. 2017. Indigeneity Discourse within Kurdish Political Movement. Securitologia 2. http://dx.doi.org/10.4467/24497436SCU.17.007.9636.

Van Bruinessen, Martin. 1992. Agha, Shaikh, and State: The Social and Political Structures of Kurdistan. New Jersey: Zed Books Ltd.

Vernon, Paul. 1997. Odeon Records: Their 'Ethnic' Output. https://www. mustrad.org.uk/articles/odeon.htm. Accessed 15 June 2020.

Ward, Jonathan. 2010. Abdul-Wahad Ahmad - Qoyrat. https://excavatedshellac. com/category/iraq/. Accessed 15 June 2020.

Yüksel, Metin. 2011. Dengbêj, Mullah, Intelligentsia: The Survival and Revival of the Kurdish-Kurmanji Language in the Middle East, 1925-1960. Doctoral dissertation, University of Chicago. Chicago, IL.

\section{Discography}

Kawîs Ä̈a. [CD] Silêmanî, Iraq: Kurdish Heritage Institute.

\section{Interviews}

Abdullah Abbas. 2019. Interviewed by author, Silêmanî, 6 October.

Sherko Hamasalih Chingiani. 2019. Interviewed by author, Silêmanî, 28

November. 